\title{
Textural and Microstructural Properties of Set Yoghurt Produced from Goat Milk Treated by Homogenization and Thermosonication
}

\author{
Eman Saad Ragab ${ }^{1.2 *}$, Sameh Said Yacoub ${ }^{2}$, Khaled Sobhy Nassar ${ }^{1,2}$ Shuwen Zhang ${ }^{1}$, Jiaping Lv ${ }^{1}, *$
}

\begin{abstract}
Thermosonication (TS) prior to conventionally heated $\left(95^{\circ} \mathrm{C}\right.$ for $\left.10 \mathrm{~min}\right)$ goat milk (GM) (at an ultrasound frequency of $20 \mathrm{kHz}$ and output power $4000 \mathrm{~W}$, from 5 to 15 min) effected the preparation of yoghurts with microstructure and texture properties superior to those of control yoghurt samples produced from homogenization milk (HM) before heated at the same temperature. Thermosonication altered the secondary structure of the protein which decreased $\beta$-sheet content and increased the amount of $\alpha$-helix structure leading to increase the hydrophobicity. As well as in thermosonication milk (TSM) samples, the percentage of $\beta$-sheet structures inversely correlated with the exposure of hydrophobic regions of the protein $(r=0.79 ; r=0.84)$, while the percentage of $\alpha$-helix structure positively correlated to the increase in the surface hydrophobicity $(r=0.61 ; r=0.92)$ for GM and cow milk (CM) samples, respectively. Moreover, there were no significant aggregates observed in TS samples compared to the homogenized, before heating. Texture profile and microstructure analysis showed that the yoghurt produced from the thermosonication milk samples had higher firmness, adhesiveness, and deluxe network structure than those induced from the homogenized milk samples.
\end{abstract}

Keywords: thermosonication; goat milk; set yoghurt; hydrophobicity; secondary structure; texture profile; microstructure.

\section{INTRODUCTION}

Goat milk products are becoming increasingly popular for consumers because of the nutritional and therapeutic value that are superior to bovine milk (Slačanac et al., 2010). Yoghurt is a widespread milk product manufactures with lactic acid fermentation of milk by addition of a starter culture (El-Zahar, 2009). Whereas, yoghurt prepared from goat milk had higher nutrients compared to that prepared from cow milk (Eissa et al., 2010).

The important step in manufacture the yoghurt containing fat is homogenization. Whereas, the homogenization process could reduce the fat globule size leads to prevent fat separation (creaming) during the fermentation, decreases whey separation, and improves consistency. Besides, ultrasonic treatment could reduce the fat globule size as smaller than those obtained by conventional homogenization ( $\mathrm{Wu}$ et al., 2001; Erkaya et al., 2015). The significantly reduced size of the fat globules causes casein and some whey proteins to be absorbed onto the surface of the globules, allowing the fat droplets to mix and interact with the protein network that forms upon acidification. (Lucey et al., 1988; Titapiccolo et al., 2011).

As known, thermal treatment of milk is an important processing for the preparation of acid gel or Yoghurt since it greatly influences the physical properties and microstructure of the curd. Moreover, to achieve a good textural quality and stability in the commercial production of set type yoghurt a relatively firm (eg. $90-$ $95^{\circ} \mathrm{C}$ for $10 \mathrm{~min}$ ) pefore inoculation, which heat treatment of milk can lead to extensive denaturation of whey proteins milk, is required (Riener et al., 2010). For acid gel formation is consist from two-step as a protein denaturation and hydrophobic coagulation. While the hydrophobic regions of protein molecules are in the original state inside and exposed to the outside by heat denaturation ( Kohyama et al., 1995). (Kohyama et al., 1995; Morand et al., 2012) suggested that, the

\footnotetext{
DOI: 10.21608/asejaiqjsae.2021.211545

${ }^{1}$ Institute of Food Science and Technology,

Chinese Academy of Agricultural Sciences, Beijing 100193, China.

${ }^{2}$ Faculty of Agriculture, Damanhour University,

Damanhour 22516, Egypt.

${ }^{*}$ Corresponding authors

Eman Saad Ragab and Jiaping Lv

eman.saad@agr.dmu.edu.eg; Lvjp586@gmail.com

Mailing address: Institute of Food Science and Technology,

Chinese Academy of Agricultural Sciences,

No.2 Yuan Ming Yuan West Road,

Haidian District, Beijing, 100193, China.

Telephone number: +8610-62815542

Received November 20, 2021, Accepted, December 26, 2021.
} 
hydrophobic interaction fundamentally plays a role in the acid gel structure formation.

However, heat treatment is the most common methods for preserving food products, thermosonication could be applied as a substitutional process to heat treatment. Thermosonication at a frequency of $35 \mathrm{kHz}$ induced positive effect on the improving sensory properties, increasing the viscosity and consistency coefficient while decreasing the serum separation of the acidic milk drink (Erkaya et al., 2015). Homogenized milk by ultrasound (frequency $20 \mathrm{kHz}$, amplitude 150 $750 \mathrm{~W}$ ) caused diminution the milk fat globules size, denaturation of whey proteins and the formation of protein molecule aggregates (Sfakianakis et al., 2014)

The present study was planned to investigate the influence of thermosonication processing (goat milk heated at $95^{\circ} \mathrm{C}$ for $10 \mathrm{~min}$ prior processed at an ultrasound frequency of $20 \mathrm{kHz}$ and output power 4000 $\mathrm{W}$, for 5,10 and $15 \mathrm{~min}$ ) on the fat globule size, and the protein secondary and tertiary structure of goat milk. Also, its influence on the water holding capacity (WHC), microstructural and textural properties of its yoghurt compared to yoghurt prepared from homogenized goat milk.

\section{MATERIALS AND METHODS}

\section{Milk samples}

Goat milk (GM) and cow milk (CM) were brought from the goat farm at Hebei province (China) and cow milk farm at Beijing province (China), respectively. Table 1 shows the chemical composition of GM, and $\mathrm{CM}$, as analyzed by Beijing Dairy Cattle Center using Milko-Scan FT1 analyzer (Foss Electric, Denmark). Samples of milk were kept overnight at $4^{\circ} \mathrm{C}$ until use.

\section{Homogenization and thermosonication treatments}

The goat (HGM) and cow (HCM) milk samples were homogenized at a pressure of $20 \mathrm{MPa}$ (AH100D, ATS industrial systems limited company, China) after heating to $65^{\circ} \mathrm{C}$.

On the other hand, the thermosonication (TS) was processed by A $20 \mathrm{kHz}$ horn-transducer ultrasound processing unit (Beijing, China). The processor was fitted with an ultrasonic probe with a titanium flat tip (14 $\mathrm{mm}$ diameter). The milk samples placed in the ultrasonic machine's tank and the probe was placed at the center of the samples. Ultrasonic was performed at an output power of $3080 \mathrm{~W}$ and $25 \%$ amplitude for different time 5, 10 and $15 \mathrm{~min}$ in $3 \mathrm{~s}: 2 \mathrm{~s}$ work/rest cycles. During the sonication process, the probe's temperature was adjusted to $60^{\circ} \mathrm{C}$ and maintained the temperature control of the samples at $60^{\circ} \mathrm{C}$ by circulation hot water around the container.
All the milk samples were heat treated at $95{ }^{\circ} \mathrm{C}$ for 10 min then cooled down rapidly to $45^{\circ} \mathrm{C}$.

\section{Processed milk samples measurements}

\subsection{Fluorescence spectroscopy}

The fluorometric assay was used to determine the surface hydrophobicity or fluorescence intensity of the thermosonicated and homogenized samples according to (Qi et al., 2015), with an ELISA-like spectrophotometer assay (spark $20 \mathrm{~m}$ multimode microplate reader from TECAN, Mannedorf, Switzerland). The excitation wavelengths $(\lambda$ ex) were recorded from $290 \mathrm{~nm}$ to 360 $\mathrm{nm}$; while the emission wavelength $(\lambda \mathrm{em})$ was $340 \mathrm{~nm}$, and the bandwidths were $10 / 10$. The fluorescence spectrum was recorded four times at $25^{\circ} \mathrm{C}$.

\subsection{Fourier transform infrared (FTIR) analysis}

The changes in the secondary structure of proteins in the milk samples were assessed using the FTIR spectrum instrument (Model Tensor 27, Buruker Corporation, Germany), with an ATR crystal prism accessory. Measurements were performed by directly injecting $10 \mu \mathrm{L}$ of the untreated and thermosonication samples on the lens of the ATR crystal's surface. All measurements were carried out at four replicates at $25^{\circ} \mathrm{C}$. The obtained results were used to analyze the amide I (1600- $1700 \mathrm{~cm}^{-1}$ ) peak positions according to (Barth, 2007). Peaks corresponding to $\alpha$-helix were $\left(1648-1660 \mathrm{~cm}^{-1}\right), \beta$-sheets were $\left(1610-1636 \mathrm{~cm}^{-1}\right)$ and $\left(1682-1690 \mathrm{~cm}^{-1}\right), \beta$-turns were $\left(1661-1681 \mathrm{~cm}^{-1}\right)$, and random coils were $\left(1637-1647 \mathrm{~cm}^{-1}\right)$. Peak fit software (version 4.12, SeaSolve Software Inc) was used to analyze the data.

\subsection{Gel electrophoresis}

Sodium dodecyl sulfate-polyacrylamide gel electrophoresis (SDS-PAGE) under reducing condition was performed using (Bio-Rad-Mini-Protean tetra system Electrophoresis tank) according to ( Ragab et al., 2019). The SDS-PAGE gel was scanned by the Alpha Ease FC gel imaging system (Alpha Inc., USA).

\section{Manufacture of set yoghurt}

Processed milk (2 L) was equilibrated at $45^{\circ} \mathrm{C}$ and inoculated with $(0.2 \% \mathrm{v} / \mathrm{v})$ yoghurt starter culture freeze-dried (R-704-3332792, CHR-HANSEN, China) and mixed well. The mixture was stirred for $2 \mathrm{~min}$ and then incubated until the $\mathrm{pH}$ reached 4.6 (about $4 \mathrm{~h}$ ). Finally, the fermentation was then stopped by refrigeration the samples to $4^{\circ} \mathrm{C}$. All the yoghurt treatments (HGM, and HCM) as controls and experimental treatments (TSGM $5 \mathrm{~min}$, TSGM $10 \mathrm{~min}$, TSGM $15 \mathrm{~min}$, and TSCM $15 \mathrm{~min}$ ) were examined after one night at refrigeration temperature. Each trial was repeated three times.

\section{Texture Profile Analysis (TPA)}

Texture Profile Analysis was performed on set type 
yoghurt samples using the texture analyzer TA-HD plus (Stable Micro Systems Ltd., Godalming, UK). The TPA parameters as well as firmness (g), adhesiveness (g. s), cohesiveness, springiness $(\mathrm{mm})$, gumminess (g) and chewiness (g. $\mathrm{mm}$ ) values were calculated from the obtained profiles using the software provided by Stable Microsystems. The cylindrical aluminum probe (P/36R; $36 \mathrm{~mm}$ DIA, aluminium radiused AACC) was used at a speed of $2.0 \mathrm{~mm} \mathrm{~s}^{-1}$ and a depth of $10 \mathrm{~mm}$ into the samples. The test was assayed on samples at $4^{\circ} \mathrm{C}$ that were kept in the refrigerator one night before testing. Each sample was measured for 3 replicates.

\section{Water Holding Capacity (WHC \%)}

The water holding capacity was determined in triplicate after $50-\mathrm{mL}$ plastic tubes containing $20 \mathrm{~mL}$ of yoghurt were centrifuged at $3000 \times \mathrm{g}$ for $10 \mathrm{~min}$.

WHC $\%=$ (yoghurt weight - weight of supernatant released/yoghurt weight) $\times 100$.

\section{Scanning electron microscopy (SEM)}

SEM was performed to observe the changes in the gel microstructure according to (Ragab et al., 2020). Drained yoghurt samples obtained after centrifugation at $4000 \times \mathrm{g}$ for $10 \mathrm{~min}$ were cut into small pellets. That pellets fixed by $2.5 \mathrm{~g} / 100 \mathrm{~g}$ glutaraldehyde in a 0.02 $\mathrm{mol} / \mathrm{L}$ sodium phosphate buffer $(\mathrm{pH} 7.2)$ for $3 \mathrm{~h}$ at $7^{\circ} \mathrm{C}$. After that the segments were postfixed with $1 \%$ osmium acid for $2 \mathrm{~h}$, and then dried using a Leica CPD $030 \mathrm{CO} 2$ critical point dryer. The dried and fractured segments were mounted on aluminum SEM stubs, using a carbonbased tape and coated with gold in a DC sputter coater (HITACHI MC1000). Photomicrographs were recorded

(a)

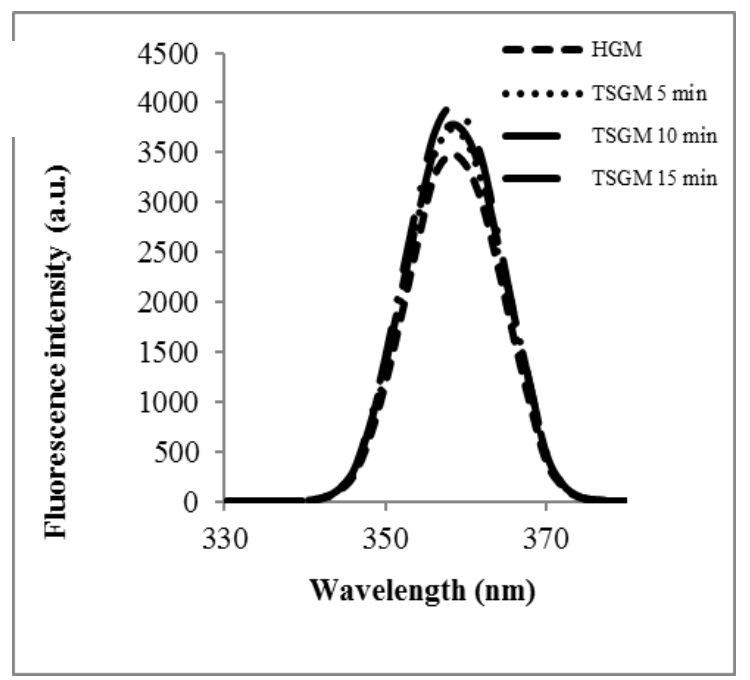

at $\times 2000$ magnification. Typical micrographs representing each yoghurt sample are present.

\section{Statistical analysis}

All tests were carried out in triplicates, and each value represents the mean of three readings; whiles the error bars represent the standard deviations. Analysis of variance (ANOVA) was conducted using the software statistical analysis systems (SAS), version 9.3 for Windows (SAS Institute Inc., city, USA). The probability level of $5 \%(\alpha=0.05)$ was used to indicate the significance, using LSD procedure.

\section{RESULTS AND DISCUSSION}

\section{Change in secondary, tertiary structures and SDS- PAGE of processed milk samples}

\subsection{Fluorescence spectroscopy}

The fluorescence intensity scan with ELISA technique, as the near-UV spectrum of a protein, was used to determine the rigidity of the amino acids of phenylalanine, tyrosine, and tryptophan. Those amino acids are often fluorescent when excited by UV light, referred to the changes in the protein tertiary structure (including the protein subunits dissociated or expansion of peptide chains) (Kelly and Price, 2000). Even the goat milk has a differential arrangement of the phosphate groups compared to cow milk (Domagała, 2012; Delgado et al., 2017). Fig. 1 elucidated the changes in the fluorescence intensity during thermosonication treatment with time variations and homogenized milk samples. The fluorescence intensity scan for the goat and milk samples were ranged between $(3500-4000 \mathrm{au}$, and $2500-2790 \mathrm{au})$, Respectively (Fig.1).

(b)

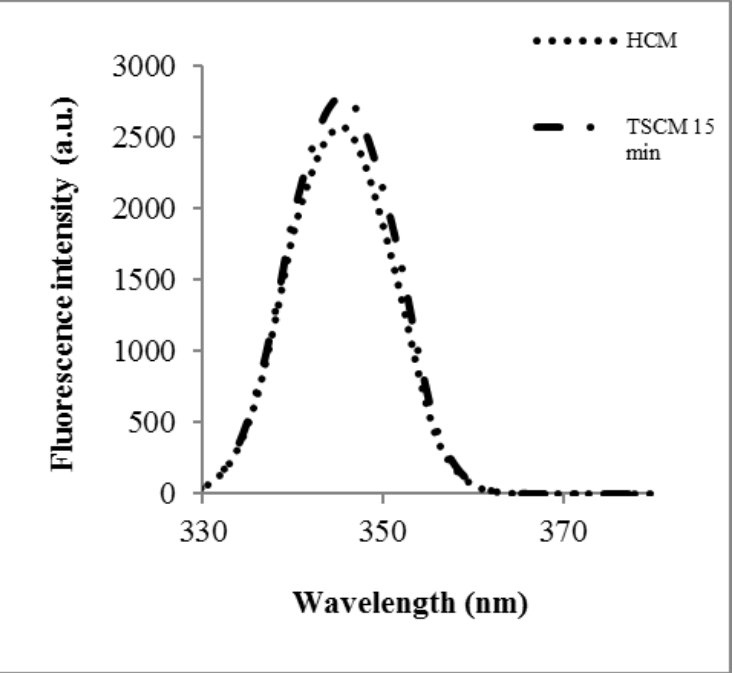

Fig. 1. Changes in the fluorescence intensity of homogenized and thermosonication goat milk (a) and cow milk (b). 
On the other hand, thermosonication milk samples (TSM) showed an increase in the fluorescence intensity compared with the controls (HGM and HCM). Hu et al. (2013) reported similar results about the cavitation phenomenon of the ultrasonic which has longer ultrasonic times $(>20 \mathrm{~min})$ increased of the hydrophobicity of soybean protein isolate after heat denaturation treatment. Dependent in our previous study, our results suggested that the thermosonication treatment induced the destruction of partial hydrophobic interactions of the protein molecules which exhibited of hydrophobic domains previously buried in the interior (exposure to the aqueous medium of initially buried amino acid groups) of the protein molecules. Furthermore, hydrophobic interactions of neutral protein molecules can become more preponderant to encourage the aggregation and lead to formation of more compact aggregates (Kohyama et al., 1995). Morand et al. (2012) founded that the high surface hydrophobicity of the whey protein complexes, or model milk influenced the microstructure of the acid gels which gave earlier and firmer.

\subsection{Fourier transform infrared (FTIR) analysis}

Fig. 2 shows the thorough FTIR spectra (400-4000 $\mathrm{cm}^{-1}$ ) of the TSM and HM samples while amide I $\left(1600-1700 \mathrm{~cm}^{-1}\right)$ of the FTIR spectra region has been marked. The peak position changes in amide I revealed that the secondary structure had been altered.

The percentage of amide I regions related to the secondary structure contents of the TSM, and HM samples are enumerated in Table 2. In general, the amounts of apparent $\beta$-sheet and $\alpha$-helix were the most important type in the protein secondary structure observed. The protein secondary structural changes observed upon thermosonication time. As shown in Table 2 , the $\beta$-sheet structure content was decreased in the TSM samples compared to the HM samples. Both the TSGM and TSCM samples were follow the same route for decreasing the $\beta$-sheet content and increasing the amount of $\alpha$-helix structure (Table 2). For the TSGM samples, the $\beta$-sheet content steadily decreased significantly $(\mathrm{p} \leq 0.05)$ to $38.88,37.93$ and $36.89 \%$ for TSGM $5 \mathrm{~min}$, TSGM $10 \mathrm{~min}$ and TSGM $15 \mathrm{~min}$, respectively compared to the HGM sample (43.68\%). Furthermore, the $\beta$-sheet TSCM $15 \mathrm{~min}$ was significantly $(\mathrm{p} \leq 0.05)$ decreased to $28.29 \%$ respected to the HCM (37.46\%). Meanwhile, the amount of $\alpha$ helix structures was significantly $(\mathrm{p} \leq 0.05)$ increased in the TSGM samples with increase the duration up to 10 min, whereas there were no significant differences $(p>$ 0.05 ) at TSGM 5 min. At TSCM $15 \mathrm{~min}$, the $\alpha$-helix content was increased to $29.98 \%$, higher than the control (HCM) that was $18.14 \%$ (Table2). The increasing in the $\alpha$-helix contents was attributed to the partial unfolding of the $\alpha$-helical region, induced by the ultrasound cavitation, while the $\beta$-sheet content was decreased compared with that in the homogenization milk samples.

The percentage of $\beta$-sheet structures inversely correlated with the exposure of hydrophobic regions of the protein $(r=0.79 ; r=0.84)$ for $\mathrm{GM}$ and $\mathrm{CM}$ samples, respectively. (Fig. $3 \mathrm{a} \& \mathrm{~b}$ ). While, in thermosonication samples, the percentage of $\alpha$-helix structure positively correlated to the increase in the surface hydrophobicity $(r=0.61 ; r=0.92)$ for GM and $\mathrm{CM}$ samples (Fig. 3c\&d). Our results were agree with Wang et al. (2014) who reported that the $\beta$-sheet structure was found permanently within the folded molecule and its partial loss indicates exposure of the hydrophobic group of protein that can induce an increase in surface hydrophobicity.

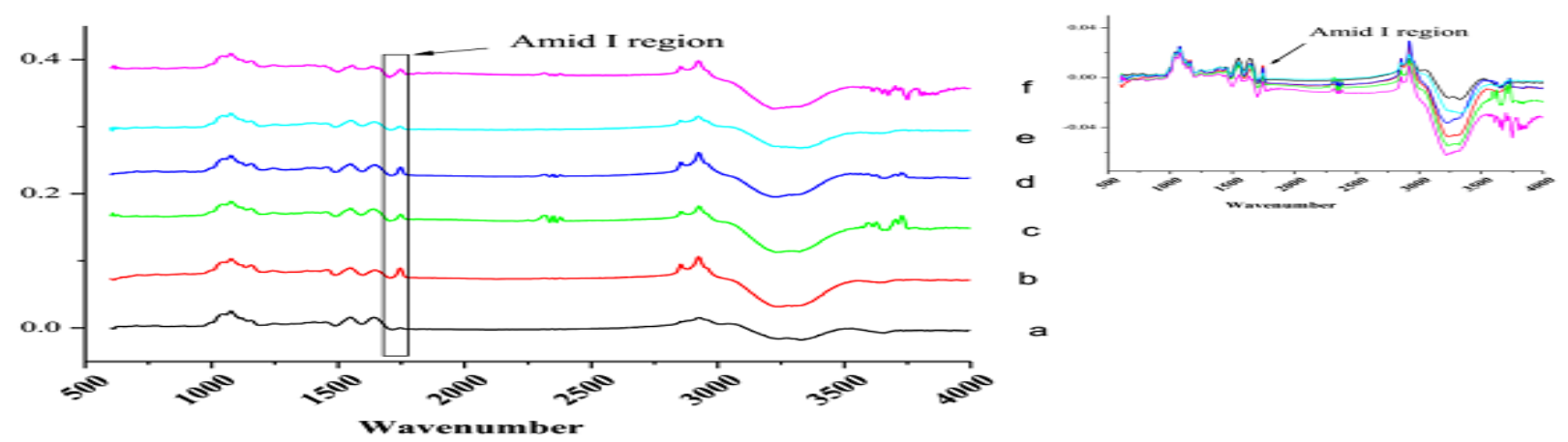

Fig. 2. Fourier transform infrared (FTIR) spectra of homogenized goat milk (HGM) at (a), thermosnicated goat milk (TSGM) for $5 \mathrm{~min}(\mathrm{~b}), 10 \mathrm{~min}(\mathrm{c}), 15 \mathrm{~min}$ (d), homogenized cow milk (HCM) (e) and thermosnicated cow milk (TSCM) for $15 \mathrm{~min}(\mathrm{f})$. 
Table 1. Chemical analyses of milk.

\begin{tabular}{lcccc}
\hline Milk & Protein $(\boldsymbol{\%})$ & Fat $(\boldsymbol{\%})$ & Lactose $(\boldsymbol{\%})$ & Total solid $(\boldsymbol{\%})$ \\
\hline Goat milk & 3.27 & 3.69 & 5.0 & 12.66 \\
Cow milk & 3.14 & 3.33 & 5.19 & 12.36 \\
\hline
\end{tabular}

Mean values calculated from 3 independent replicates.

Table 2. Changes in the secondary structure of homogenized and thermosonication milk samples.

\begin{tabular}{lcccc}
\hline & \multicolumn{4}{c}{ Secondary structure } \\
\cline { 2 - 5 } Items* $^{*} \boldsymbol{\beta}$-Sheet & $\boldsymbol{\alpha}$ - Helix & Random coil & $\boldsymbol{\beta}$-turn \\
\hline HGM & $43.68 \pm 0.04^{\mathrm{a}}$ & $14.51 \pm 1.25^{\mathrm{c}}$ & $17.21 \pm 1.4^{\mathrm{b}}$ & $24.61 \pm 2.7^{\mathrm{ab}}$ \\
TSGM 5 min & $38.88 \pm 1.37^{\mathrm{b}}$ & $16.11 \pm 2.3^{\mathrm{c}}$ & $16.54 \pm 2.9^{\mathrm{b}}$ & $27.46 \pm 3.92^{\mathrm{a}}$ \\
TSGM 10 min & $37.93 \pm 0.22^{\mathrm{bc}}$ & $18.13 \pm 0.12^{\mathrm{b}}$ & $20.58 \pm 0.09^{\mathrm{a}}$ & $23.36 \pm 0.02^{\mathrm{b}}$ \\
TSGM 15 min & $36.89 \pm 0.09^{\mathrm{c}}$ & $18.14 \pm 0.17^{\mathrm{b}}$ & $20.54 \pm 0.01^{\mathrm{a}}$ & $24.14 \pm 0.25^{\mathrm{ab}}$ \\
HCM & $37.46 \pm 1.6^{\mathrm{bc}}$ & $18.14 \pm 0.13^{\mathrm{b}}$ & $20.34 \pm 0.14^{\mathrm{a}}$ & $24.07 \pm 1.33^{\mathrm{ab}}$ \\
TSCM15 min & $28.29 \pm 0.02^{\mathrm{d}}$ & $29.98 \pm 0.03^{\mathrm{a}}$ & $16.55 \pm 0.06^{\mathrm{b}}$ & $25.18 \pm 0.01^{\mathrm{ab}}$ \\
\hline
\end{tabular}

* HGM: homogenized goat milk; TSGM 5 min: thermosonication goat milk for 5 min; TSGM 10 min: thermosonication goat milk for $10 \mathrm{~min}$; TSGM $15 \mathrm{~min}$ : thermosonication goat milk for $15 \mathrm{~min}$; HCM: homogenized cow milk, and TSCM 15 min: thermosonication cow milk for $15 \mathrm{~min}$.

The values are mean \pm SD of determinations made in triplicates. Different letters indicate significant differences $(\mathrm{P}<0.05)$ between the milk samples.
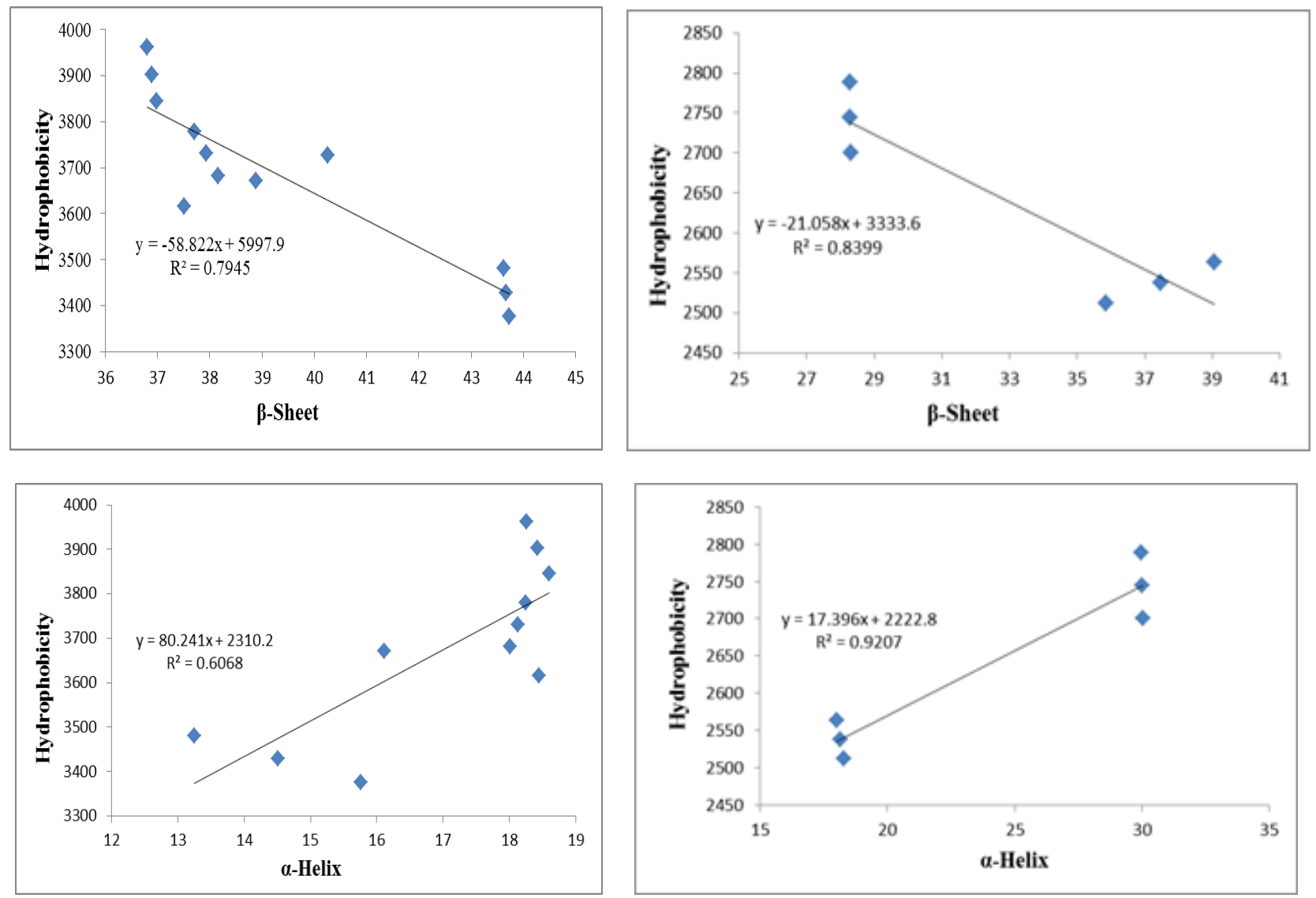

Fig. 3. Correlation between the hydrophobicity and $\beta$ - sheet of the goat milk samples (a) and cow milk samples (b). And correlation between the hydrophobicity and $\alpha$ - helix content of the goat milk samples (c) and cow milk samples (d). 
Moreover, those authors observed that there was no significant correlation between surface hydrophobicity and secondary structure of soybean protein isolate after heat treatments at $90^{\circ} \mathrm{C}$. So, in our study, we suggested that the changes in the secondary structure of the milk protein resulted in the ultrasound cavitation. The higher amount of $\alpha$-helix structure in skim milk in comparison to caseins could due to presence of well-structured whey proteins including $\alpha$-la and $\beta-\lg$ (Mediwaththe et al., 2018).

On the other hand, the results of the random coil in the TSGM samples showed a significant increase after thermosonication time $\geq 10 \mathrm{~min}$ when compared to the HGM. The random coil content was increased from $17.21 \%$ for HGM to $20.34 \%$ for TSGM 15 min. The sonicated goat milk (at $20 \mathrm{kHz}$ for 15 to $30 \mathrm{~min}$ ) showed a significant increase in the random coil (Ragab et al., 2020). The opposite trend is shown in the TSCM samples at $15 \mathrm{~min}(16.55 \%)$ which showed a significant decrease in the random coil compared to HCM (20.34 $\%)$. Whereas the reduction in the random coil content in the TSCM samples than the HCM, the values of $\beta$-turns content of the thermosonication milk samples showed an increment (Table 2). In general, the changes in the amount of random coil structure attributed to the $\beta$-turns content whether it was increased or decreased. Previous studies reported that the ultrasonic treatment could alter the secondary structure of the milk protein (Zhang et al., 2018; Ragab et al., 2020). Wang et al. (2014) suggested that heating caused an increase the amount of $\alpha$-helix structure and decreased the $\beta$-sheet structure in soybean protein isolate samples compared with the untreated, that transformation from $\beta$-sheet to both $\alpha$-helix and $\beta$ turn occurred in soybean protein isolate heat treated, leading to an increased surface hydrophobicity.

\subsection{SDS-PAGE}

SDS-PAGE was applied to demonstrate whether an increase in hydrophobicity could change the interaction between protein molecules and lead to the formation of molecular complexes or aggregates. Whereas there were no significant diminishes were observed in the bands of the SDS page for homogenized and thermosonicated milk samples (Fig.4), the heat generated during thermosonication was insufficient to denature the whey proteins. Thus, the whey proteins denaturation of $(\alpha-1 \mathrm{a}$ and $\beta-\lg$ ) was resulted in the heat temperature of pasteurization at $95^{\circ} \mathrm{C}$ for $10 \mathrm{~min}$ for the milk sample and could associate with $\mathrm{k}-\mathrm{CN}$ as showed a decrease in its bands of all the samples (Fig.4). Those the whey proteins denaturation due to heating could associate not only with themselves but also with the k-CN to form bridges between the casein particles leading to a narrow pored casein network (Schorsch et al., 2001). Nguyen and Anema, (2010) found that the temperature of the skim milk was increased during ultrasonication treatment $(22.5 \mathrm{kHz}$ and an output power of $50 \mathrm{~W})$ without temperature control to about $95^{\circ} \mathrm{C}$ after $\geq 15$ min, significant denaturation of the whey proteins was observed on the samples for longer than $5 \mathrm{~min}$, which stage the temperature was above $70^{\circ} \mathrm{C}$. Even the conventional heating denatured almost $50 \%$ of the whey proteins; the ultrasonic treatment denatured only about $25 \%$ of the whey proteins (Riener et al., 2009).

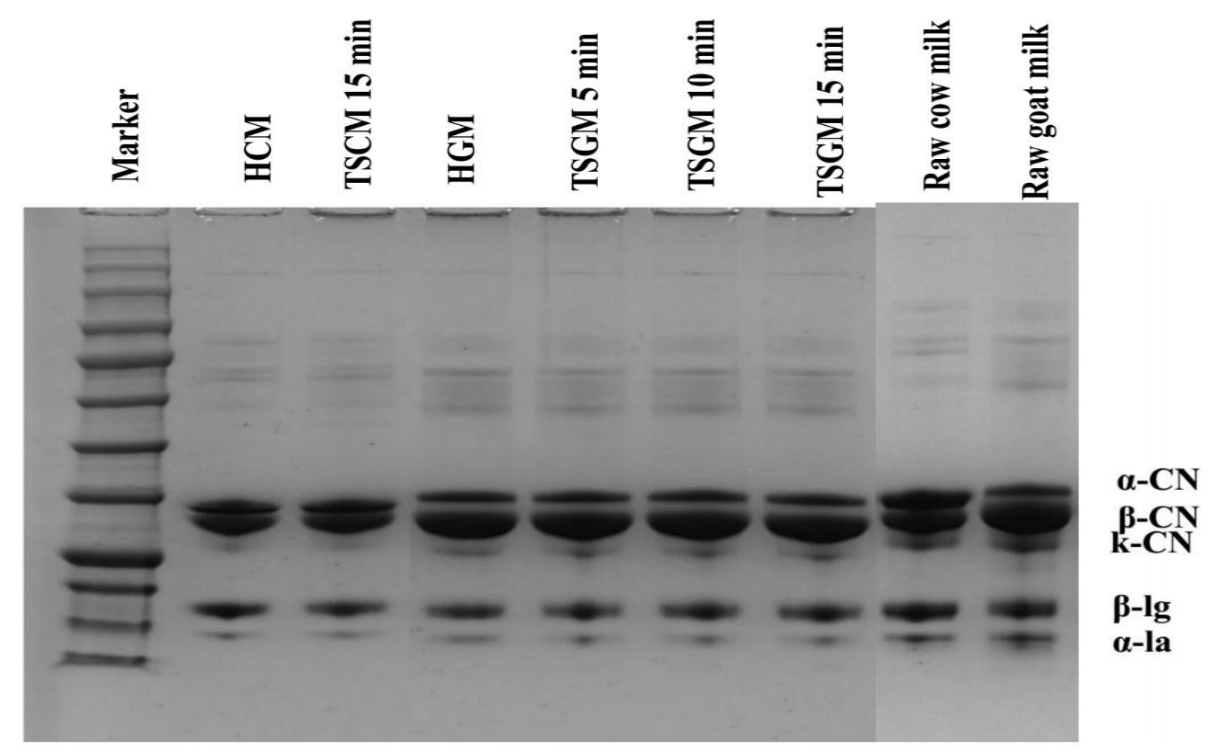

Fig. 4. SDS PAGE of raw, homogenized and thermosonication goat and cow milk samples. 


\section{Physical properties and microstructure of set yoghurt samples}

\subsection{Texture Profile Analysis (TPA)}

The results of TPA of the set yoghurt obtained from TSM, and HM samples are shown in Table 3. In general, yoghurt obtained from GM is characterized by lower texture values than the yoghurt induced from CM. One of the most important attributes for a set yoghurt quality is texture. As indicated in Table 3 yoghurt obtained from TSM samples was markedly higher firmness than the yoghurt of HM samples with mean values of 111, 130.6, 144.1 and $199.9 \mathrm{~g}$ for TSGM $5 \mathrm{~min}$, TSGM $10 \mathrm{~min}$, TSGM $15 \mathrm{~min}$ and TSCM $15 \mathrm{~min}$, respectively compared to the HGM (99.7 g) and HCM (178.1 g). Nguyen and Anema, (2010) noted that the firmness was altered when skim milk was ultrasonically treated (without temperature control) prior to acidification to be higher than those prepared from skim milk that were only heated. According the casein micelles of GM are smaller, have a lower proportion of the $\alpha_{\mathrm{s}_{1}}$-casein and lower diameter of the fat globules, revealed the lower firmness than the yoghurt from CM samples (Delgado et al., 2017).

In respect of the other textural properties, yoghurt samples from TSM showed higher adhesiveness, cohesiveness, springiness, gumminess and chewiness than the homogenized. Nonetheless, in the case of the yoghurt obtained from TSGM for 15 min showed the highest increase in adhesiveness, springiness, gumminess, and chewiness compared to the HGM as the mean values of (189 vs. $74.6 \mathrm{~g} \mathrm{~s}, 0.973$ vs. 0.957 $\mathrm{mm}, 66.71$ vs. $50.95 \mathrm{~g}$ and 61.55 vs. $47.82 \mathrm{~g} . \mathrm{mm}$ ), respectively (Table 3).

Similar observations were evident for the increasing in those texture parameters were showed the yoghurt from TSCM respected to the yoghurt from HCM.
Whereas the adhesiveness, cohesiveness, gumminess, and chewiness of the yoghurt from TSCM 15 min were (350.9 vs. $202.6 \mathrm{~g} \mathrm{~s}, 0.39$ vs. $0.34,79.09$ vs. $60.78 \mathrm{~g}$ and 78.05 vs. 57.92 g. $\mathrm{mm}$ ), respectively while the springiness parameter was almost the same as in yoghurt from HCM (Table 3). Meanwhile, there was significant decrease in the cohesiveness values of the yoghurt from 0.51 to 0.46 for the yoghurt obtained from HGM and from TSGM 15 min samples, respectively. The cohesiveness indicates the ability of the product to hold together while, springiness relates to product deformation during storage and transportation. Therefore, the value of the springiness is very important for the quality of the product at the required level (Yildiz et al., 2015). Similar values of the cohesiveness for goat's yoghurt supplemented with whey protein concentrate and cow's yoghurt (Herrero and Requena, 2006).

Even gumminess is defined as the product of hardness or firmness and cohesiveness, yoghurt with high hardness value also had a high gumminess value (Table 3). The chewiness values of the yoghurt changed between (47.82 -78.05). Yagmur and Kose, (2019) reported that the chewiness value of the industrial yogurt samples was in the range of 11.87 to 112.61 .

\subsection{Water Holding Capacity (WHC)}

WHC is a critical parameter in yogurt manufacturing since it related with syneresis, which evidences the internal stability of the gel (Wu et al., 2001). The set yoghurt obtained from TSM resulted in a higher WHC than that obtained from HM samples (Fig. 5). However, in the yoghurt of TSGM samples, WHC was showed steadily increase up to $95 \%$ in TSGM 15 min compared that was the yoghurt from HGM (89 \%). Furthermore, the set yoghurt from TSCM 15 min was $85 \%$ respected to the HCM (78\%) (Fig.5).

Table 3. Texture profile analysis parameters (mean \pm SD) of intact acid gel samples.

\begin{tabular}{lcccccc}
\hline Items* & $\begin{array}{c}\text { Firmness } \\
(\mathbf{g})\end{array}$ & $\begin{array}{c}\text { Adhesiveness } \\
(\mathbf{g} . \mathbf{s})\end{array}$ & Cohesiveness & $\begin{array}{c}\text { Springiness } \\
(\mathbf{m m})\end{array}$ & $\begin{array}{c}\text { Gumminess } \\
(\mathbf{g})\end{array}$ & $\begin{array}{c}\text { Chewiness } \\
(\mathbf{g} . \mathbf{m m})\end{array}$ \\
\hline HGM & $99.7 \pm 3.54^{\mathrm{f}}$ & $-74.6 \pm 1.06^{\mathrm{a}}$ & $0.51 \pm 0.005^{\mathrm{a}}$ & $0.957 \pm 1.32^{\mathrm{b}}$ & $50.99^{\circ} \pm 1.33^{\mathrm{e}}$ & $47.82 \pm 1.31^{\mathrm{e}}$ \\
TSGM 5 min & $111 \pm 7.70^{\mathrm{e}}$ & $-100 \pm 0.87^{\mathrm{b}}$ & $0.48 \pm 0.002^{\mathrm{b}}$ & $0.974 \pm 3.58^{\mathrm{a}}$ & $54.00^{\wedge} \pm 3.58^{\mathrm{de}}$ & $55.19 \pm 3.57^{\mathrm{d}}$ \\
TSGM 10 min & $130.6 \pm 2.44^{\mathrm{d}}$ & $-159 \pm 0.12^{\mathrm{c}}$ & $0.43 \pm 0.001^{\mathrm{d}}$ & $0.969 \pm 1.07^{\mathrm{a}}$ & $57.26 \pm 1.07^{\mathrm{d}}$ & $55.99 \pm 0.71^{\mathrm{d}}$ \\
TSGM 15 min & $144.1 \pm 5.81^{\mathrm{c}}$ & $-189.7 \pm 0.12^{\mathrm{d}}$ & $0.46 \pm 0.150^{\mathrm{c}}$ & $0.973 \pm 4.86^{\mathrm{a}}$ & $66.71 \pm 4.86^{\mathrm{b}}$ & $61.55 \pm 4.78^{\mathrm{b}}$ \\
HCM & $178.1 \pm 9.52^{\mathrm{b}}$ & $-202.6 \pm 0.47^{\mathrm{d}}$ & $0.34 \pm 0.012^{\mathrm{f}}$ & $0.968 \pm 1.13^{\mathrm{a}}$ & $60.78 \pm 1.13^{\mathrm{c}}$ & $57.92 \pm 1.30^{\mathrm{c}}$ \\
TSCM15 min & $199.9 \pm 0.001^{\mathrm{a}}$ & $-350.9 \pm 0.13^{\mathrm{e}}$ & $0.39 \pm 0.001^{\mathrm{e}}$ & $0.976 \pm 0.11^{\mathrm{a}}$ & $79.09 \pm 0.11^{\mathrm{a}}$ & $78.05 \pm 1.26^{\mathrm{a}}$ \\
\hline
\end{tabular}

* HGM: homogenized goat milk; TSGM 5 min: thermosonication goat milk for 5 min; TSGM 10 min: thermosonication goat milk for $10 \mathrm{~min}$; TSGM $15 \mathrm{~min}$ : thermosonication goat milk for $15 \mathrm{~min}$; HCM: homogenized cow milk, and TSCM 15 min: thermosonication cow milk for $15 \mathrm{~min}$. 


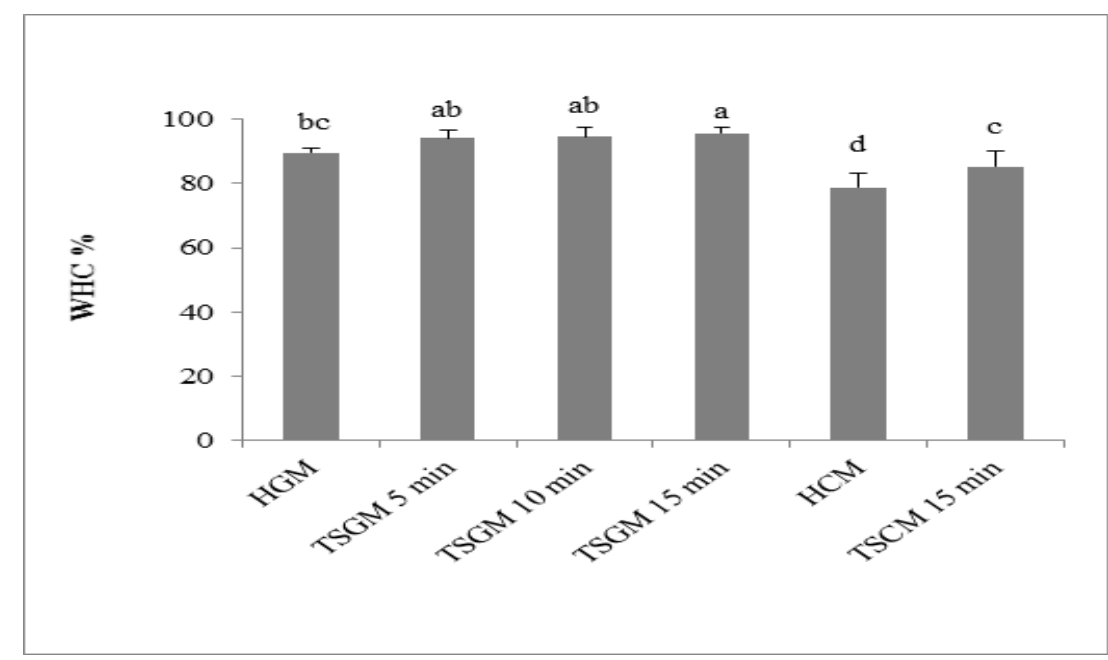

Fig. 5. Water holding capacity (WHC \%) of the yoghurt produced from goat and cow milk samples.

Even the yoghurt from GM samples showed higher WHC \% than that from CM samples because of the protein and fat content in GM were higher than those in cow milk (Table 1). The yoghurt cultures prepared from thermosonication of milk (3.5 fat \%) were markedly improved the WHC to $89 \%$ compared to conventionally produced yoghurts (42\%) (Riener et al., 2009; Riener et al., 2010). Those authors also reported that the WHC was strongly influenced by the fat content. Whereas they showed an increase in WHC with the high level-fat in thermosonication treated yoghurt. Independent in our previous study ( Ragab et al., 2019) we suggest that the main reason for increasing the water holding capacity attributed to ultrasound cavitation, which induced a reduction in the fat globules, subsequently total fat membrane surface area increased. Therefore, the increased amount of membrane included a lot of newbonded casein, which would be hydrophilic. Besides, the changes in the secondary structure attributed to the cavitation forces of ultrasound-induced higher hydrophobicity of the proteins (Table $2 \&$ Fig. 1). This explanation agrees with the research of Kinsella and Morr (1984); Wu et al. (2001); Morand et al. (2012).

\subsection{Microstructure by SEM}

The microstructures of yogurt gels made from TS and $\mathrm{H}$ milk samples are depicted in Fig. 6. SEM showed differences in the microstructure, the yoghurt of $\mathrm{HM}$ samples had much larger clusters of protein aggregates with bigger pores size mimicking the microstructure of honeycomb (Fig. 6a\& e). However, yoghurt gels of thermosonication milk clearly showed a dense crosslinked network structures with a high level of interconnections and exhibited a lot of pores as smaller sizes throughout the structures (Fig. 6b, c, d \& f).
The microstructure was found to be related to firmness and susceptibility to WHC. Similar types of microstructures were observed in gels made from TSGM and TSCM (Fig. 6b, c, d and Fig. 6 f), respectively. Indeed, heat treatment is classically employed in the manufacture of acid milk gels or yoghurt to improve its texture and microstructure. Hence, thermosonication beside the pasteurization can not only homogenize the fat globules but also can promote the functional properties of the protein leading to strengthening the structure of goat yoghurt or cow yoghurt. Riener et al. (2009) investigated the differences in the microstructure of yoghurt prepared from TSM which showed a honeycomb like network and exhibiting a more porous nature throughout the structure.

\section{CONCLUSIONS}

Our results demonstrated that the TS process on GM could alter the secondary structure of the protein, leading to enhance hydrophobicity. The applied TS treatments increased the $\alpha$-helix and decreased the $\beta$ sheet structure content, which related to the changes in the hydrophobicity. Furthermore, TS could use as an alternative process to homogenization because of the positive effects on textural properties, microstructure, and WHC of the set yoghurt compared to those obtained from the HM. These improvements were particularly marked in the microstructure and textural properties of yoghurt from TSGM. Additionally, thermosonication may be a useful alternative to the use of texture modifying additives to enhance the quality of the yoghurt manufactured from GM. 

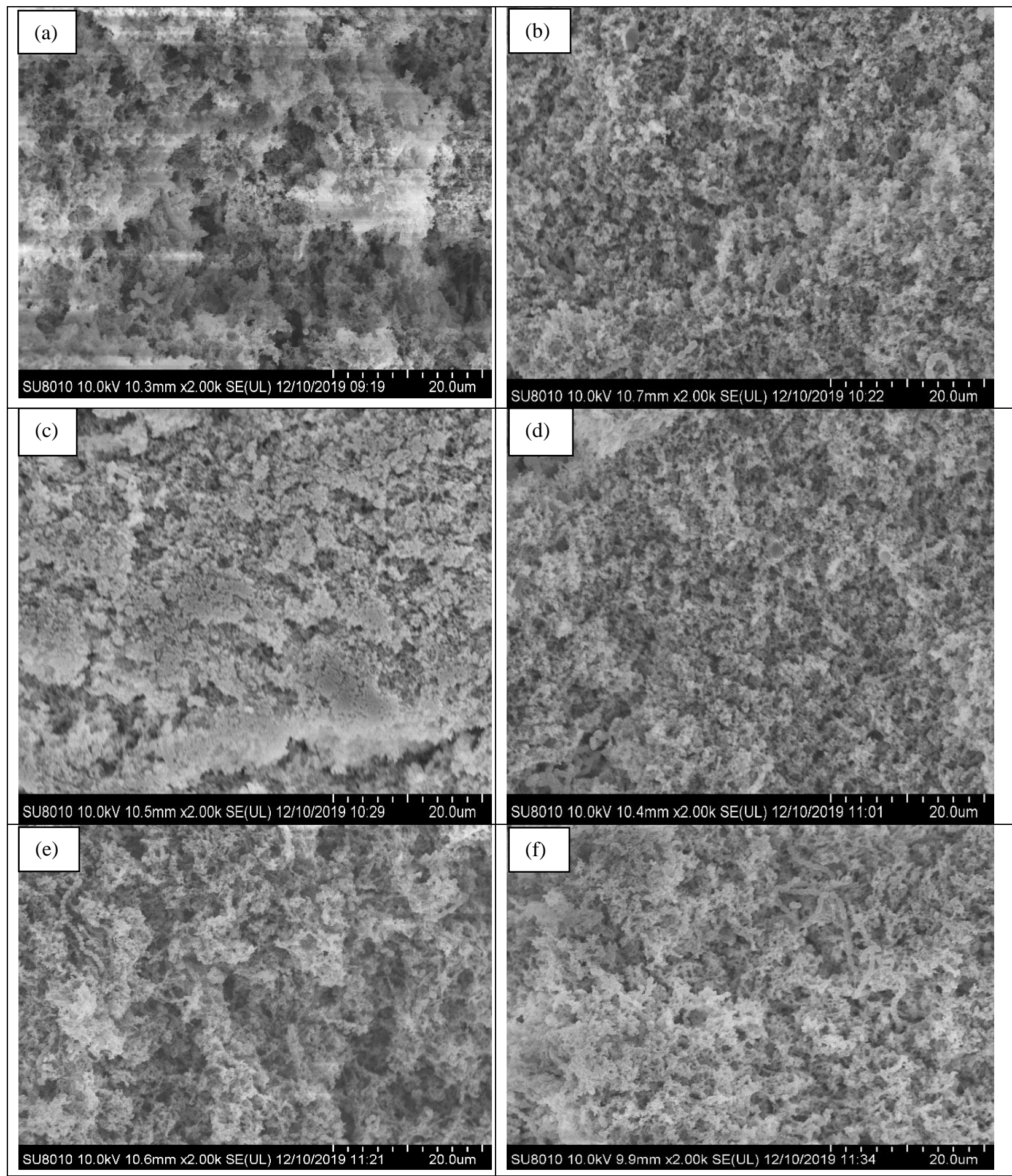

Fig. 6. Scanning electron micrographs of set yoghurt obtained from goat and cow milk samples processed by homogenized (a) HGM, (e) HCM; and thermosonication (b) TSGM 5 min, (c) TSGM 10 min, (d) TSGM 15 min, (f) TSCM 15 min. 


\section{ACKNOWLEDGEMENT}

This work was supported by National Natural Science Foundation of China (Grant No. 31871834), National Key R\&D Program of China (2018YFD0400900), Beijing innovation of Technology System in Dairy Industry.

\section{REFERENCES}

Barth, A. 2007. Infrared spectroscopy of proteins. Biochimica et Biophysica Acta - Bioenergetics.1767(9):1073-1101.

Delgado, K.F., S. Frasao, M. Pereira, C. Adam and C. Junior. 2017. Different Alternatives to Improve Rheological and Textural Characteristics of Fermented Goat Products - A Review, Rheol. Open Access. 1(1):1-6.

Domagała, J. 2012. Instrumental texture, syneresis, and microstructure of yoghurts prepared from ultrafiltrated goat milk: Effect of degree of concentration. International Journal of Food Properties. 15(3): 558568.

Eissa, E.A., I.A.M. Ahmed, A.E.A. Yagoub and E.E. Babiker .2010. Physicochemical, microbiological and sensory characteristics of yoghurt produced from goat milk. Livestock Research for Rural Development. 22(8): 281-286.

El-Zahar, Kh. 2009. Antimicrobial Activity of Sheep Yoghurt Prepared by Different Commercial Starter Strains. Alex. Sci . Exch. J. 30: 187-197.

Erkaya, T., M. Başlar, M. Şengül and M.F. Ertugay .2015. Effect of thermosonication on physicochemical, microbiological and sensorial characteristics of ayran during storage. Ultrasonics Sonochemistry. 23:406-412

Herrero, A.M and T. Requena .2006. The effect of supplementing goats milk with whey protein concentrate on textural properties of set-type yoghurt. International journal of food science \& technology. 41(1):87-92.

Hu, H., X. Fan, Z. Zhou, X. Xu, G. Fan, L. Wang and L. Zhu .2013. Acid-induced gelation behavior of soybean protein isolate with high intensity ultrasonic pretreatments. Ultrasonics Sonochemistry. 20(1):187-195.

Kelly, S and N. Price .2000. The Use of Circular Dichroism in the Investigation of Protein Structure and Function. Current Protein \& Peptide Science.1(4):349-384.

Kinsella, J.E and C.V. Morr .1984. Milk proteins: physicochemical and functional properties. Critical Reviews in Food Science \& Nutrition. 21(3):197-262.

Kohyama, K., Y. Sano and E. Doi .1995. Rheological Characteristics and Gelation Mechanism of Tofu (Soybean Curd). Journal of Agricultural and Food Chemistry. 43(7):1808-1812.

Lucey, J.A., P.A. Munro and H. Singh .1988. Rheological Properties and Microstructure of Acid Milk Gels as Affected by Fat Content and Heat Treatment. Journal of Food Science. 63(4): 660-664.
Mediwaththe, A., D. Bogahawaththa and M. Kaur .2018. Structural changes of native milk proteins subjected to controlled shearing and heating. Food Research International. 114: 151-158.

Morand, M., A. Dekkari, F. Guyomarc'h and M.H. Famelart .2012. Increasing the hydrophobicity of the heatinduced whey protein complexes improves the acid gelation of skim milk. International Dairy Journal. 25(2): 103-111.

Nguyen, N.H.A and S.G. Anema .2010. Effect of ultrasonication on the properties of skim milk used in the formation of acid gels. Innovative Food Science and Emerging Technologies.11(4): 616-622.

Qi, P.X., D. Ren, Y. Xiao and P.M. Tomasula .2015. Effect of homogenization and pasteurization on the structure and stability of whey protein in milk1. Journal of Dairy Science. 98(5): 2884-2897.

Ragab, E.S., J. Lu, X.Y. Pang, K.S. Nassar, B.Y. Yang, S.W. Zhang and J.P. Lv .2019. Effect of thermosonication process on physicochemical properties and microbial load of goat's milk. Journal of Food Science and Technology. 56(12): 5309-5316.

Ragab, E.S., S. Zhang, X. Pang, J. Lu, K.S. Nassar, B. Yang and J. Lv .2020. Ultrasound improves the rheological properties and microstructure of rennet-induced gel from goat milk. International Dairy Journal. 104642.

Riener, J., F. Noci, D.A. Cronin, D.J. Morgan and J.G. Lyng .2009. The effect of thermosonication of milk on selected physicochemical and microstructural properties of yoghurt gels during fermentation. Food Chemistry. 114(3): 905-911.

Riener, J., F. Noci, D.A. Cronin, D.J. Morgan and J.G. Lyng .2010. A comparison of selected quality characteristics of yoghurts prepared from thermosonicated and conventionally heated milks. Food Chemistry. 119(3): $1108-1113$.

Schorsch, C., D.K. Wilkins, M.G. Jones and I.T. Norton .2001. Gelation of casein-whey mixtures: Effects of heating whey proteins alone or in the presence of casein micelles. Journal of Dairy Research. 68(3): 471-481.

Sfakianakis, P., E. Topakas and C. Tzia .2014. Comparative Study on High-Intensity Ultrasound and Pressure Milk Homogenization: Effect on the Kinetics of Yogurt Fermentation Process. Food and bioprocess technology. 8(3): 548-557.

Slačanac, V., R. Božanić, J. Hardi, J.R. szabó, judit, M. lučan and V. Krstanović .2010. Nutritional and therapeutic value of fermented caprine milk. International Journal of Dairy Technology. 63(2):171189.

Titapiccolo, G.I., M. Corredig and M. Alexander .2011. Acid coagulation behavior of homogenized milk: Effect of interacting and non-interacting droplets observed by rheology and diffusing wave spectroscopy. Dairy Science and Technology. 91(2):185-201. 
Wang, Z., Y. Li, L. Jiang B. Qi and L. Zhou .2014. Relationship between Secondary Structure and Surface Hydrophobicity of Soybean Protein Isolate Subjected to Heat Treatment. Journal of Chemistry.1-10.

Wu, H., G.J. Hulbert and J.R. Mount .2001. Effects of ultrasound on milk homogenization and fermentation with yogurt starter. Innovative Food Science \& Emerging Technologies. 1(3):211-218.

Yagmur, K and S. Kose .2019. Determination of texture profile analysis of yogurt produced by industrial and traditional method. International Journal of Scientific and Technological Research. 4(8):66-70.
Yildiz, O., B. Yurt, O.S. Toker, M.M. Ceylan, M.T. Yilmaz and A. Bastürk .2015. Pasting, textural and sensory characteristics of the kofter, a fruit-based dessert: Effect of molasses and water concentration. International Journal of Food Engineering. 11(3):349-358.

Zhang, R., X. Pang, J. Lu, L. Liu, S. Zhang and J. Lv 2018. Effect of high intensity ultrasound pretreatment on functional and structural properties of micellar casein concentrates. Ultrasonics sonochemistry. 47:1016.

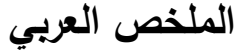

\section{خواص القوام والتركيب البنائى الدقيق لليوغورت الجالس المنتج من لبن الماعز المعامل بالتجنيس والموجات فوق الصوتية مع الحرارة}

\author{
Jiaping Lv, Shuwen Zhang, إيمان سعد رجب، سامح سعيد يعقوب، خالد صبحي نصار
}

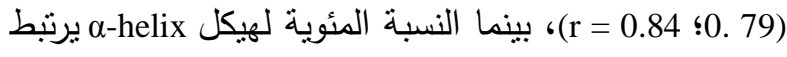

إيجابيًا بالزيادة في كره الماء السطحي (r = لعينات لبن الماعز ولبن الابقارعلى التوالي. علاوة على ذلك، لم تكن هناك مجاميع كبيرة لوحظت في عينات اللبن المعامل بالموجات فوق الصوتية مع الحرارة مقارنة باللبن المجنس قبل

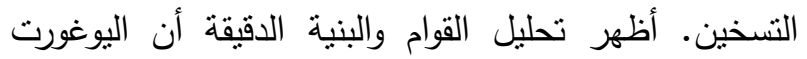
المنتج من عينات اللبن المعاملة بالموجات فوق الصوتية مع الحرارة كان له صلابة، قدرة على الالتصاق، بنية قوام جيدة أعلى من تلاك الموجودة فى اليوغورت الناتج من عينات اللبن المجنس.

الكلمـات الدالة: الموجات فوق الصسوتية مـع الحرارة، لبن المـاعز ، اليوغورت الجـالس، الجزيئـات المحبـة للمـاء، البنيـة الثانوية، خواص القوام والتركيب البنائى الدقيق.
تهدف الدراسة الى استخدام تقنية الموجات فوق الصوتية مع الحرارة (TS) قبل المعاملة الحرارية (90 درجة مئوية لمدة

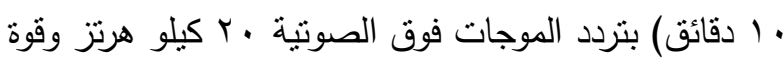
الإخراج . . .. واط، من 0 إلى 10 دقيقة) مقارنة بالتجنيس في انتاج اليوغورت الجالس باستخدام لبن الماعز (GM). أظهرت النتائج ان خصائص البنية الدقيقة والقوام تقوق عينات اليوغورت الكنترول المنتج من اللبن المجنس (HM) قبل تسخينه بنفس درجة الحرارة. الموجات فوق الصوتية مع الحرارة احدثت تغيير في البنية الثانوية للبروتين مما أدى إلى تقليل محتوى البروتين من النوع (sheet) وزيادة محتواه من النوع (a-helix) مما أدى إلى زيادة كره الماء. وكذلك في عينات اللبن المعامل بالموجات فوق الصونية هع الحرارة (TSM)، فإن النسبة المئوية لهياكل الصفائح م-sheet r = ترتبط عكسياً بتعرض المناطق الكارهة للماء من البروتين 